\title{
Effect of Maternal Age on Milk Production Traits, Fertility, and Longevity in Cattle
}

\author{
B. Fuerst-Waltl, ${ }^{1}$ A. Reichl, ${ }^{1}$ C. Fuerst, ${ }^{2}$ R. Baumung, ${ }^{1}$ and J. Sölkner ${ }^{1}$ \\ ${ }^{1}$ Department of Livestock Sciences, University of Natural Resources and Applied Life Sciences, \\ Vienna, Gregor Mendel-Strasse 33, A-1180 Vienna, Austria \\ ${ }^{2}$ ZuchtData EDV-Dienstleistungen GmbH, Dresdner Strasse 89/19, A-1200 Vienna, Austria
}

\begin{abstract}
Longevity is the economically most important functional trait in cattle populations. However, with an increased productive lifespan, the number of offspring born by older dams increases. A higher maternal age might have negative effects on the performance of offspring. The objective of this study was to investigate the effect of maternal age on production (energy-corrected milk yield $[\mathrm{ECM}]$ ) and functional traits (fertility; somatic cell score, and functional longevity) in Austrian dual-purpose Simmental cows. Age of dam had a significant effect on ECM yield and longevity. The ECM yield of daughters decreased with age of dam. Although the risk of culling slightly increased with age of dam, it was lowest for daughters of oldest dams. Results for fertility were non-significant, and results for somatic cell scores were inconsistent across parities.
\end{abstract}

(Key words: milk production, fertility, longevity, maternal age)

Abbreviation key: ECM = energy-corrected milk, $\mathbf{N R 9 0}=$ non-return rate at $90 \mathrm{~d}$.

\section{INTRODUCTION}

Longevity is an essential part of any breeding goal, reflecting the ability of an animal to cope successfully with the environmental conditions in a given production system. In Austrian dual-purpose Simmental cattle, longevity is the economically most important functional trait per genetic standard deviation in the total merit index (Miesenberger et al., 1998). However, by trying to increase the productive lifespan of livestock, the number of offspring born by older mothers also increases. One major effect of parental age, mainly maternal age, on postnatal development in mammals is due to chromosomal abnormalities, especially fetal an-

Received January 8, 2004.

Accepted February 12, 2004

Corresponding author: B. Fuerst-Waltl; e-mail: birgit.fuerstwalt1@boku.ac.at. euploidy. The finite ovaria stock of primary follicles and oocytes are produced only before birth in most mammals. Meiosis is resumed in the oocytes of mature follicles just before ovulation (Finch, 1990). Nucleus and mitochondrial DNA damage, which is frequently observed (Richter et al., 1988), may be the result of the prolonged prophase of meiosis in germ cells. In addition to the higher probabilities of chromosomal abnormalities in connection with higher parental age, there is also evidence of transmissible and cumulative effects of parental age on their offspring. In rotifers, clones from older mothers had shorter lifespans (Lansing, 1947, 1948). A recent study in Drosophila (Hercus and Hoffmann, 2000) showed that females from old mothers and grandmothers had the lowest viability.

Wang and vom Saal (2000) showed that offspring of very young and older mothers in mice had lower BW and delayed puberty. This result seemed to be related to levels of serum testosterone and estradiol varying with maternal age. In addition, subsequent generations were also affected as the birth weight of females' offspring depended on the age at pregnancy of their grandmothers.

Another explanation for the maternal age effect in insects is the resource depletion hypothesis. Females might be physiologically limited in their ability to produce identically sized offspring. This theory was supported by the findings of Yanagi and Miyatake (2002). Bruchid beetle, Callosobruchus chinensis, showed a decreasing egg size and egg number with maternal age. However, this decline with age was significantly greater for females without food than with food, indicating a possible compensation for the depletion of resources.

The effect of maternal age was also analyzed in humans according to the mitochondrial theory of aging. Mitochondrial DNA is assumed to be the major target of oxidative damage and may, therefore, be responsible for the age-related accumulation of the genetic load (Wallace, 1994). Evidence for this theory was found by Gavrilov et al. (1997). Daughters of older mothers had a reduced lifespan, but sons did not seem to be affected. The latter might have been caused by a higher pre- or postnatal mortality, however. 
Table 1. Number of daughter records, means, and standard deviations for both data sets (total and restricted to dams living for at least $10 \mathrm{yr}$ ).

\begin{tabular}{|c|c|c|c|c|}
\hline \multirow[b]{2}{*}{ Trait } & \multicolumn{2}{|c|}{ Total data set } & \multicolumn{2}{|c|}{ Restricted data set } \\
\hline & $\mathrm{n}$ & $\overline{\mathrm{x}} \pm \mathrm{s}$ & $\mathrm{n}$ & $\overline{\mathrm{x}} \pm \mathrm{s}$ \\
\hline $\mathrm{ECM}^{1}$ (1st lactation, $\mathrm{kg}$ ) & 118,847 & $4702 \pm 1153$ & 38,647 & $4591 \pm 1108$ \\
\hline ECM (2nd lactation, kg) & 86,370 & $5342 \pm 1314$ & 30,126 & $5273 \pm 1285$ \\
\hline ECM (3rd lactation, kg) & 63,312 & $5520 \pm 1329$ & 23,302 & $5490 \pm 1317$ \\
\hline SCS (1st lactation) & 15,948 & $1.64 \pm 1.01$ & 4112 & $1.64 \pm 1.10$ \\
\hline SCS (2nd lactation) & 13,359 & $2.07 \pm 1.19$ & 4063 & $2.04 \pm 1.18$ \\
\hline SCS (3rd lactation) & 11,068 & $2.35 \pm 1.25$ & 3884 & $2.32 \pm 1.22$ \\
\hline Non-Return Rate (\%) & 88,026 & $65.4 \pm 47.6$ & 28,538 & $65.3 \pm 47.9$ \\
\hline Longevity (Hazard rate) & - & - & 167,878 & $1^{2}$ \\
\hline
\end{tabular}

${ }^{1} \mathrm{ECM}=$ Energy-corrected milk.

${ }^{2}$ No standard deviation available.

Thus far, little attention has been paid to the maternal age effect on the performance of offspring in livestock. Hence, the objective of this study was to investigate the effect of maternal age on production and functional traits of dual-purpose Simmental cows. Economics forms the background for livestock production and, therefore, strongly influences the available data, especially with respect to the actual lifespan of the animals. However, compared with other species, a large number of reliable data has been recorded in livestock for a long time, particularly in cattle.

\section{MATERIALS AND METHODS}

\section{Data and Traits}

Data of Austrian dual-purpose Simmental cows and their daughters from the federal country Lower Austria were used. Apart from the usual data checks, the total data set was restricted to dams older than $2 \mathrm{yr}$ and younger than $16 \mathrm{yr}$. The effect of age of dam at birth on the performance of her daughter was analyzed for the economically most important traits in Austria's dairy cattle total merit index, i.e., length of productive life (functional longevity), fertility (non-return rate at $90 \mathrm{~d}$ [NR90]), SCS, and energy-corrected milk (ECM) yield. Records for functional longevity and ECM have been available since 1979, and records for NR90 and SCS have been available since 1990 .

A long herd life of a cow substantially decreases the replacement costs per lactation and enables a cow to achieve her maximum capacity of performance when attaining full maturity. In addition, the potential for a long herd life resting on good health and fertility reduces treatment costs and the incidence of involuntary culling. Therefore, longevity, particularly functional longevity (longevity corrected for milk performance), is of primary interest in dairy cattle breeding. In this context, culling for low productivity is disregarded, as performance is used as a different selection criterion. Only culling for health problems or other non-production causes is taken into account (Essl, 1998).

Fertility is an essential trait in dairy cattle breeding and is crucial for milk production. The non-return-rate is one of the most widely used traits to express fertility in cattle (Thaller, 1997). The NR90 in the Austrian breeding value estimation describes whether a cow or heifer is inseminated a second time within $90 \mathrm{~d}$ from the first insemination.

The SCC is an important health trait, as it is highly correlated with clinical and subclinical mastitis (Philipsson et al., 1995). Economically, penalty systems for high SCC in the milk are also of importance in dairy cattle breeding. The SCS, which is used in the genetic estimation, is a log transformation of the SCC (Boichard and Rupp, 1997).

Finally, the milk performance trait ECM is the 305$\mathrm{d}$ milk yield in the first, second, and third lactation corrected for fat and protein percentage. The ECM not only is a main production trait, but it also allows one to draw conclusions about the energy output and balance of an animal.

Number of total daughter records per trait, means, and standard deviations are shown in Table 1.

\section{Statistical Analyses}

For analyses, the following age classes for dams were defined: $1=2$ to $3.99 \mathrm{yr}, 2=4$ to $5.99 \mathrm{yr}, 3=6$ to 7.99 $\mathrm{yr}, 4=8$ to $9.99 \mathrm{yr}, 5=10$ to $11.99 \mathrm{yr}$, and $6=12$ to 16 yr. To avoid a possible bias by dams with short longevity, analysis was additionally carried out for a restricted data set with dams living for at least $10 \mathrm{yr}$. In the total data set, early age classes include dams that had offspring only in these classes, whereas each dam in the restricted data set had the chance to have daughters in several age classes. The restriction was used to safeguard against a potential bias caused by 


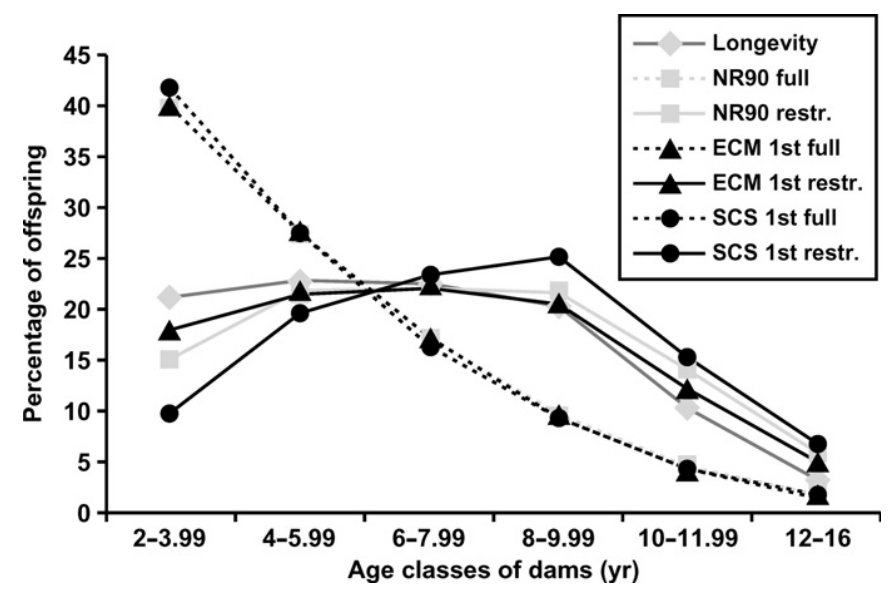

Figure 1. Percentage of daughters in different age classes of dams for functional longevity (restricted data set only), non-return rate (NR90), first lactation energy corrected milk yield (ECM), and first lactation somatic cell score (SCS).

incomplete separation of additive genetic and age of dam effects in the statistical models described subsequently. Including only dams that survived to $>10 \mathrm{yr}$ may invoke a different kind of bias because cows surviving so long are not typical for the population. The proportion of daughters in different age classes of dams for all traits and both data sets is shown in Figure 1.

Calculations for ECM yield, SCS, and fertility were carried out using the computer program PEST (Groeneveld, 1990). The number of animals in the pedigree file was 217,673 for ECM, 221,526 for NR90, and 145,635 for SCS. The same pedigree files were used for the separate analysis of the 3 lactations (ECM and SCS) and for total and restricted data sets. Genetic groups were not included. By taking the random additive genetic effect of animal into account, a possible bias caused by genetic change over time should be avoided.

The following statistical models were used for testing the effect of age of dam on performance of her daughter:

ECM yield. $\mathrm{Y}_{\mathrm{ijklmno}}=\mu+(\text { rhys })_{\mathrm{ijkl}}+$ age $_{\mathrm{m}}+\mathrm{a}_{\mathrm{n}}+$ $\varepsilon_{\mathrm{ijklmno}}$, where $\mathrm{Y}_{\mathrm{ijklmno}}=$ individual observation $(\mathrm{kg}$ of ECM yield in the first, second, or third lactation); $\mu=$ overall mean; $(\text { rhys })_{i j k l}=$ fixed interaction effect of region $\mathrm{i}$, herd class $\mathrm{j}$, year $\mathrm{k}$, and season $\mathrm{l}$; age $_{\mathrm{m}}=$ fixed effect of age class of dam $\mathrm{m} ; \mathrm{a}_{\mathrm{n}}=$ random additive genetic effect of animal, and $\varepsilon_{\mathrm{ijk} k m n o}=$ random residual. Data were precorrected for age at calving, calving interval, and DIM until first test day according to Potucek (1996). The heritabilities were $0.30,0.25$, and 0.22 for the first, second, and third lactations, respectively.

SCS. $\mathrm{Y}_{\mathrm{ijklmnop}}=\mu+(\text { hy })_{\mathrm{ij}}+\mathbf{c m}_{\mathrm{k}}+\mathbf{c a}_{\mathrm{l}}+$ samp $_{\mathrm{m}}+$ age $_{\mathrm{n}}$ $+\mathrm{a}_{\mathrm{o}}+\varepsilon_{\mathrm{ijk} \text { knnop }}$, where $\mathrm{Y}_{\mathrm{ijk} \text { lmnop }}=$ individual observation (average SCS in the first, second, or third lactation), $\mu=$ overall mean, $(\text { hy })_{\mathrm{ij}}=$ fixed interaction effect of herd $\mathrm{i}$ and year $\mathrm{j}, \mathrm{cm}_{\mathrm{k}}=$ fixed effect of month of calving $\mathrm{k}$, $\mathrm{ca}_{\mathrm{l}}=$ fixed effect of age at calving $\mathrm{l}, \mathrm{samp}_{\mathrm{m}}=$ effect of number of samples $\mathrm{m}$, age $\mathrm{n}_{\mathrm{n}}=$ fixed effect of age class of dam $n, a_{0}=$ random additive genetic effect of animal, and $\varepsilon_{\mathrm{ijklmnop}}=$ random residual. Although for the breeding value estimation, a test day model was used, the logarithm of the average SCC was taken for this analysis. A minimum of 6,5 , and 4 milk samples had to be available for the first, second, and third lactation, respectively. The heritabilities were $0.10,0.15$, and 0.13 for the first, second, and third lactations, respectively.

Fertility. $\mathrm{Y}_{\mathrm{ijklmnopqr}}=\mu+(\mathrm{hy})_{\mathrm{ij}}+\mathrm{ms}_{\mathrm{k}}+(\mathrm{psp})_{1 \mathrm{~m}}+$ age $_{n}+$ sire $_{o}+$ cow $_{p}+$ pe $_{q}+\varepsilon_{\mathrm{ijklmnopqr}}$, where $\mathrm{Y}_{\mathrm{ijklmnopqr}}=$ individual observation (NR90); $\mu=$ the overall mean; $(\text { hy })_{i j}=$ fixed interaction effect of herd $\mathrm{i}$ and year $\mathrm{j}$; $\mathrm{ms}_{\mathrm{k}}=$ fixed effect of month of service $\mathrm{k} ;(\mathrm{psp})_{1 \mathrm{~m}}=$ fixed interaction effect of parity $l$ and age at first service $m$ (first parity) or parity $\mathrm{l}$ and service period $\mathrm{m}$ (subsequent parities), respectively; age $_{n}=$ fixed effect of age class of dam $\mathrm{n}$; sire $_{0}=$ random paternal genetic effect of the sire used for the insemination; $\operatorname{cow}_{p}=$ random maternal genetic effect of the inseminated animal; $\mathrm{pe}_{\mathrm{q}}=$ random permanent environmental effect of the inseminated animal; and $\varepsilon_{\mathrm{ijk} k m n o p q r}=$ the random residual. Only herds with 20 or more observations were analyzed. The heritabilities were 0.02 for male and female fertility each, and no correlation between male and female fertility was assumed (Thaller et al., 1994).

Because of computational limitations, hypothesis tests were carried out with the GLM procedure of SAS (1988). The same models, excluding the random additive genetic effect of animal, were used.

The computer program SURVIVAL KIT (Ducrocq and Sölkner, 1999) was used for analysis and hypothesis test of the longevity data set. The computer program is not based on an animal model but a sire-maternal grandsire model. Only the restricted data set was investigated to be sure that the effect of the age of the dam did not interfere with the genetic effect of longevity. Because of the restriction to dams living for at least 10 yr, dams could have offspring in all age classes. Genetic groups were not included, the number of sires and maternal grandsires in the pedigree was 9006 and 8059, respectively. The heritability used was 0.12 (Fuerst and Egger-Danner, 2002b). The following model was applied.

Functional longevity. $\mathrm{h}(\mathrm{t}, \mathrm{z})=\mathrm{h}_{0}(\mathrm{t}) * \exp \left[(\mathrm{rys})_{\mathrm{ijk}}\right.$ $+(\mathrm{ysh})_{\mathrm{jkl}}+\mathrm{afc}_{\mathrm{m}}+(\mathrm{stl})_{\mathrm{no}}+$ milk $_{\mathrm{p}}+$ fatprot $_{\mathrm{q}}+$ hsize $_{\mathrm{r}}+$ age $_{\mathrm{s}}+$ sire $_{\mathrm{t}}+0.5$ mgsire $_{\mathrm{u}}$, where $\mathrm{h}(\mathrm{t}, \mathrm{z})=$ the hazard of a cow $t$ days after her first calving; $h_{0}(t)=$ Weibull baseline hazard function; $(\mathrm{rys})_{\mathrm{ijk}}=$ fixed interaction effect of region i, year $\mathrm{j}$, and season $\mathrm{k}$; $(\mathrm{ysh})_{\mathrm{jkl}}=$ random interaction effect of year $\mathrm{j}$, season $\mathrm{k}$, and herd $\mathrm{l}$ assum- 
Table 2. Deviations from age class 1 of dams for energy-corrected milk (ECM), SCS, and non-return rate at $90 \mathrm{~d}$ (NR90) and both data sets (total and restricted to dams living for at least $10 \mathrm{yr}$ ).

\begin{tabular}{lllccc}
\hline & \multicolumn{5}{c}{ Age class of dams } \\
\cline { 2 - 6 } Trait & 2 & 3 & 4 & 5 & 6 \\
\hline Total data set & & & & \\
ECM (1st lactation, kg) & -30 & -56 & -83 & -113 & -144 \\
ECM (2nd lactation, kg) & -35 & -57 & -89 & -104 & -170 \\
ECM (3rd lactation, kg) & -31 & -73 & -90 & -111 & -148 \\
SCS (1st lactation) & +0.01 & \pm 0 & +0.05 & -0.08 & -0.02 \\
SCS (2nd lactation) & -0.01 & -0.03 & -0.08 & -0.13 & -0.16 \\
SCS (3rd lactation) & +0.01 & -0.02 & -0.08 & -0.05 & +0.08 \\
NR90 (\%) & -0.5 & \pm 0.0 & +0.7 & -0.4 & +1.2 \\
Restricted data set & & & & & -188 \\
ECM (1st lactation, kg) & -35 & -81 & -118 & -152 & -212 \\
ECM (2nd lactation, kg) & -27 & -83 & -122 & -144 & -178 \\
ECM (3rd lactation, kg) & -1 & -71 & -106 & -136 & +0.09 \\
SCS (1st lactation) & +0.03 & +0.05 & +0.07 & -0.04 & -0.19 \\
SCS (2nd lactation) & -0.09 & -0.02 & -0.10 & +0.03 & +0.14 \\
SCS (3rd lactation) & +0.02 & +0.07 & +0.02 & -1.4 & -0.2 \\
NR90 (\%) & -2.1 & -1.1 & -0.2 & -0.0 \\
\hline
\end{tabular}

ing a log-gamma distribution with gamma $=4.0 ;$ afc $_{\mathrm{m}}=$ fixed effect of age at first calving $\mathrm{m}$; (stl) no $_{\mathrm{o}}=$ time-dependent fixed interaction effect of stage of lactation $n$ and lactation $0 ;$ milk $_{\mathrm{p}}=$ time-dependent fixed effect of relative milk yield within herd $\mathrm{p}$; fatprot $_{\mathrm{q}}=$ time-dependent fixed effect of relative fat plus protein percentage within herd q; hsize $_{\mathrm{r}}=$ time-dependent fixed effect of change of herd size $\mathrm{r}$; age $_{\mathrm{s}}=$ fixed effect of age class of dam $\mathrm{s}$; sire $_{t}=$ random sire genetic effect $;$ and mgsire ${ }_{u}=$ random maternal grandsire genetic effect. The assumed value for $\rho$ was 2.0.

Apart from the fixed effect of age class of dam, the same models and precorrections as for the Austrian breeding value estimation were used for all traits. More detailed descriptions may be found in Potucek (1996) (milk yield), Reents (1995) (SCS), Thaller et al. (1994) and Fuerst and Egger-Danner (2002a) (fertility), and Fuerst and Egger-Danner (2002b) (functional longevity).

\section{RESULTS AND DISCUSSION}

For ECM, SCS, and NR90, the deviations from age class 1 for age classes 2 to 6 of the dams and both data sets are shown in Table 2 (models including the random additive genetic effect). Generally, means for age classes of dams were similar with or without genetic effect in the model. In both data sets, the ECM milk yield of daughters decreased with age of dam. The effect of age of dam was significant with $P<0.001$ for all lactations and both data sets. The difference in ECM yield between lowest and highest age class of dam was $144 \mathrm{~kg}$ (total data set, first lactation) to $212 \mathrm{~kg}$ (restricted data set, second lactation). The same result was found for milk, fat, and protein yield when analyzed separately. If older dams have lower breeding values for ECM, this should be accounted for by including the additive genetic effect and by using the restricted data set. An explanation for this result could, therefore, be that quantitative traits such as milk yield are affected by many loci. The longer an egg cell in the ovary is exposed to negative environmental effects, the higher is the probability of mutations of at least some loci. Alakhverdov and Maslennikov (1973) also observed the highest milk yield of daughters resulting from first and second calvings in Russian Simmental. In other studies (Polyakov, 1979; Piech and Tarkowski, 1999), parity of dams did not affect the milk yield of their daughters. However, the number of animals was relatively small in these investigations (500 and 1200, respectively); in this study, between 20,000 and 120,000 records were analyzed.

The results for SCS were inconsistent. For the total data set, the age of dam was significant for first lactation offspring $(P<0.01)$. In second lactation offspring, a trend of decreasing SCS with increasing age of dam could be observed $(P=0.052)$. However, the effect of age of dam was not significant in the third lactation and was not significant for any of the lactations of the reduced data set. This result may be due to the fact that the SCC is mainly affected by the lactating cow itself as shown by Kennedy et al. (1982) and Emanuelson and Persson (1984). In addition, distinctly fewer data (Table 1) were available for SCS compared with ECM, as data recording started several years later and data sets were restricted to a minimum number of milk samples per lactation. Generally, management or environmental effects strongly influence functional traits, 
Table 3. Hazard rates for daughters of dams in different age classes (restricted to dams living for at least $10 \mathrm{yr}$ ).

\begin{tabular}{lllllll}
\hline & \multicolumn{6}{c}{ Age class of dams } \\
\cline { 2 - 7 } & 1 & 2 & 3 & 4 & 5 & 6 \\
\hline Hazard rate of daughters & 0.98 & 1.00 & 1.01 & 1.02 & 1.01 & 0.90 \\
\hline
\end{tabular}

which may also explain that no significant effect of maternal age on the NR90 could be found $(P=0.55$ for the total and $P=0.24$ for the restricted data set). In mice, maternal age affected fertility by delaying puberty (Wang and vom Saal, 2000). Only traits for which breeding values are estimated were analyzed in this study. However, age at first calving might be another fertility trait worthy of investigation in further studies.

The hazard rate for daughters of dams in different age classes is presented in Table 3. Age of dam had a significant effect on the hazard rate of their daughters $(P<0.001)$. The result for functional longevity was surprising, however. Following the results of the studies in rotifers and Drosophila (Lansing, 1947, 1948; Hercus and Hoffmann, 2000), the hazard rate slightly increased for the first 4 age classes of dams. However, the risk of culling was lowest for daughters of the oldest dams. Maybe some cows have better defense mechanisms against nucleus and mitochondrial DNA damage. They might also have better repair mechanisms and, therefore, compensate the age-dependent accumulation of genetic damage. Another reason for this result could be that the genetic effect still interferes, especially, because the model is not an animal model but a sirematernal grandsire model. As there is no clear genetic trend for longevity in this population (Fuerst and Egger-Danner, 2002b), this is not a very likely explanation. Furthermore, dams in the oldest age group may be a selected group as they might have benefited from preferential treatment. Additionally, paternal age might have influenced the performance of offspring. However, the length of productive life of sires used for artificial insemination and natural service sires is only a few years. A paternal age effect on daughter performance is most unlikely and should not have biased the results of this study.

\section{CONCLUSIONS}

From the results of studies in other species, an effect of maternal age on reproductive ability, health, and longevity of their daughters could be expected. Hence, it was rather surprising that an effect on a dairy trait (ECM yield) was found while fertility and mastitis resistance seemed to be unaffected by maternal age. As the ECM yield also reflects energy balance, the negative effect of increasing maternal age may be the consequence of cumulative effects on the energy household. However, even though the additive genetic effect was included in the model, the result for ECM might still be biased by the fact that younger mothers were genetically superior for this trait. If inclusion of the genetic effect did not avoid the problem, the restricted data set should have. The significant effect on longevity was also unexpected as the risk of culling slightly increased with age of dam, but was lowest for daughters of oldest dams.

\section{REFERENCES}

Alakhverdov, A. S., and V. N. Maslennikov. 1973. Effect of age of Simmental dams on the quality of their progeny. NauchnyeTrudy. Voronezhskii Selskokhozyaistvennyi Institut. 8:120-125.

Boichard, D., and R. Rupp. 1997. Genetic analysis and genetic evaluation for somatic cell score in French dairy cattle. Interbull Bull. 15:54-60.

Ducrocq, V., and J. Sölkner. 1999. Survival Kit, Version 3.12. [Online]. Available: http://www.boku.ac.at/nuwi/software/softskit.htm. Accessed Feb. 12, 2004.

Emanuelson, U., and E. Persson. 1984. Studies on somatic cell counts in milk from Swedish dairy cows. Non-genetic causes of variation in monthly test-day results. Acta Agric. Scand. 34:33-44.

Essl, A. 1998. Longevity in dairy cattle breeding: A review. Livest. Prod. Sci. 57:79-89.

Finch, C. E. 1990. Longevity, Senescence, and the Genome. Univ Chicago Press, Chicago, IL.

Fuerst, C., and C. Egger-Danner. 2002a. Joint genetic evaluation for fertility in Austria and Germany. Interbull Bull. 29:73-76.

Fuerst, C., and C. Egger-Danner. 2002b. Joint genetic evaluation for functional longevity in Austria and Germany. Proc. 7th World Congr. Genet. Appl. Livest. Prod., Montpellier, France. 29:103106.

Gavrilov, L. A., N. S. Gavrilova, V. G. Semenova, G. N. Evdokushkina, V. N. Krut'ko, A. L. Gavrilova, N. N. Evdokushkina, and E. V. Lapshin. 1997. Maternal age and lifespan of offspring. Doklady Biol. Sci. 354:287-289.

Groeneveld, E. 1990. PEST User's Manual. Institute of Animal Husbandry and Animal Behaviour, Federal Agricultural Research Centre, Mariensee, Germany.

Hercus, M. J., and A. A. Hoffmann. 2000. Maternal and grandmaternal age influence offspring fitness in Drosophila. Proc. R. Soc. Lond. B Biol. Sci. 267:2105-2110.

Kennedy, B. W., M. S. Sethar, A. K. W. Tong, and B. R. Downey. 1982. Environmental factors infuencing test-day somatic cell counts in Holsteins. J. Dairy Sci. 65:275-280.

Lansing, A. I. 1947. A transmissable, cumulative, and reversible factor in aging. J. Gerontol. 2:228-239.

Lansing, A. I. 1948. Evidence for aging as a consequence of growth cessation. Proc. Natl. Acad. Sci. USA 34:304-310.

Miesenberger, J., J. Sölkner, and A. Essl. 1998. Economic weights for fertility and reproduction traits relative to other traits and effects of including functional traits into a total merit index. Interbull Bull. 18:78-84.

Philipsson, J., G. Ral, and B. Berglund. 1995. Somatic cell count as a selection criterion for mastitis resistance in dairy cattle. Livest. Prod. Sci. 41:195-200.

Piech M., and J. Tarkowski. 1999. Productivity of black and white cows in subsequent calvings. Annales Universitatis Mariae Curie Sklodowska. Sectio EE Zootechnica 17:57-63.

Polyakov, P. E. 1979. Vliyanie vozrasta materei na produktinye kachestva potomstva (The effect of age of dam on the production of progeny). Puti intensifik. Kormoprva i zhivotnovod. V tsentr. R-ne nechernozemn. Zony 38-42.

Potucek, E. 1996. Zuchtwertschätzung für Merkmale der Milchleistung. Pages 7-14 in Zuchtwertschätzung beim Rind — Grundla- 
gen und aktuelle Entwicklungen. Seminar des Genetischen Ausschusses der ZAR, Salzburg, Austria, March 14, 1996. Zentrale Arbeitsgemeinschaft österreichischer Rinderzüchter, Wien, Austria.

Reents, R. 1995. Zuchtwertschätzung auf Zellzahl. Züchtungskunde. 67:461-466.

Richter, C., J. W. Park, and B. N. Ames. 1988. Normal oxidative damage to mitochondrial and nuclear DNA is extensive. Proc. Natl. Acad. Sci. USA 85:6465-6467.

SAS/STAT User's Guide, 6.03 ed. 1988. SAS Inst., Inc., Cary, NC.

Thaller, G. 1997. Genetics and breeding for fertility. Interbull Bull. 18:55-61.
Thaller, G., M. Gierdziewics, G. Averdunk, and J. Aumann. 1994. Breeding value estimation for reproductive traits by an animal model with paternal and maternal effects. In 45th Annu. Mtg. EAAP, Edinburgh, UK. EAAP, Rome, Italy.

Wallace, D. C. 1994. Mitochondrial DNA sequence variation in human evolution and disease. Proc. Natl. Acad. Sci. USA 91:8739-8746.

Wang, M.-H., and F. S. vom Saal. 2000. Maternal age and traits in offspring. Nature 407:469-470.

Yanagi, S.-I., and T. Miyatake. 2002. Effects of maternal age on reproductive traits and fitness components of the offspring in the bruchid beetle, Callosobruchus chinensis (Coleoptera: Bruchidae). Physiol. Entomol. 27:261-266. 